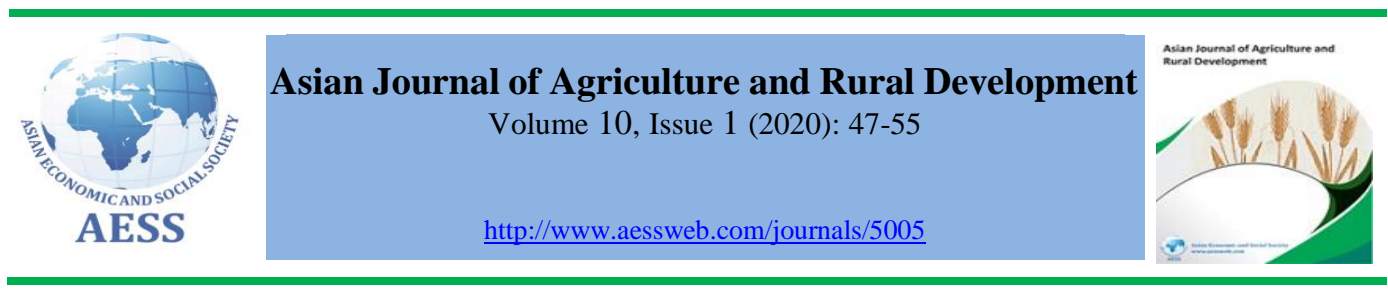

\title{
UPGRADING RURAL YOUTHS' CAPACITY FOR DRIVING SHRIMP-BASED AGRIBUSINESS VALUE CHAIN IN NIGERIA
}

\author{
Achoja Felix \\ Odemero $^{\text {a }}$ i \\ Gbigbi Theophilus Miebi ${ }^{\text {a, }}$ \\ Ikpoza Eguono Aramide a, \\ Denghan Janet Ebidenere ${ }^{a}$
}

\author{
a Department of Agricultural Economics and \\ Extension, Delta State University, Asaba \\ Campus, Nigeria \\ $\bowtie$ achojafelix@gmail.com (Corresponding \\ author)
}

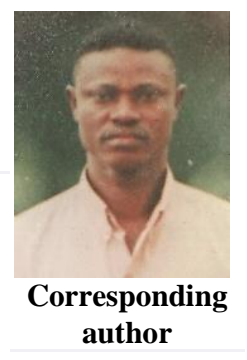

ARTICLE HISTORY:

Received: 08-Nov-2019

Accepted: 20-Feb-2020

Online Available: 02-Mar-

2020

\section{Keywords:}

Rural youths,

Capacity upgrading,

Captured-shrimp

agribusiness value chain,

Nigeria

\begin{abstract}
This study derives its significance from the current debate on ageing agricultural labour force in Nigeria and the need for capacity building of rural youth. This study investigates rural youth capacity for driving shrimp-based agribusiness development in Nigeria. Data for the study were obtained from primary sources using a structured questionnaire with randomly selected 120 shrimp operators (harvesters, processors and marketers). Statistical analytical tools (descriptive and inferential statistics) were employed to analyze the collected data. Test of the hypothesis implies that the mean income earned by youth is significantly $(\mathrm{p}<0.01)$ higher that the income of aged workforce in the shrimp agribusiness value chain. Further finding shows that human capital of youth (shrimp-oriented education, training, workshops attended and access to credit) has a positive and significant $(\mathrm{p}<0.01)$ effect on their financial performance. Incentives such as loans and aquaculture-oriented education and regular workshops should be given to the rural youth to upgrade their capacity to drive the development of shrimp-based agribusiness in Nigeria in the future.
\end{abstract}

\section{Contribution/ Originality}

The study provides empirical information for rural youths' inclusion policy for shrimp-based agribusiness, an understudied segment in Nigeria, and it is one of the latest investigations that highlight family agribusiness succession theory.

DOI: 10.18488/journal.1005/2020.10.1/1005.1.47.55

ISSN (P): 2304-1455/ISSN (E):2224-4433

How to cite Achoja Felix Odemero, Gbigbi Theophilus Miebi, Ikpoza Eguono Aramide and Denghan Janet Ebidenere (2020). Upgrading rural youths' capacity for driving shrimp-based agribusiness value chain in Nigeria. Asian Journal of Agriculture and Rural Development, 10(1), 47-55.

(C) 2020 Asian Economic and Social Society. All rights reserved. 


\section{INTRODUCTION}

Shrimp (penaus notialis) belongs to the family Penaeidae. It is a species of small aquatic animal belonging to the sub-phylum of crustaceans including lobster and crayfish (Amos and Amos, 1997; Lawal-Are and Akinjogunla, 2012). It is a proteinase sea food that is popular in the diets of most consumers all over the world including Nigeria with no cultural restrictions.

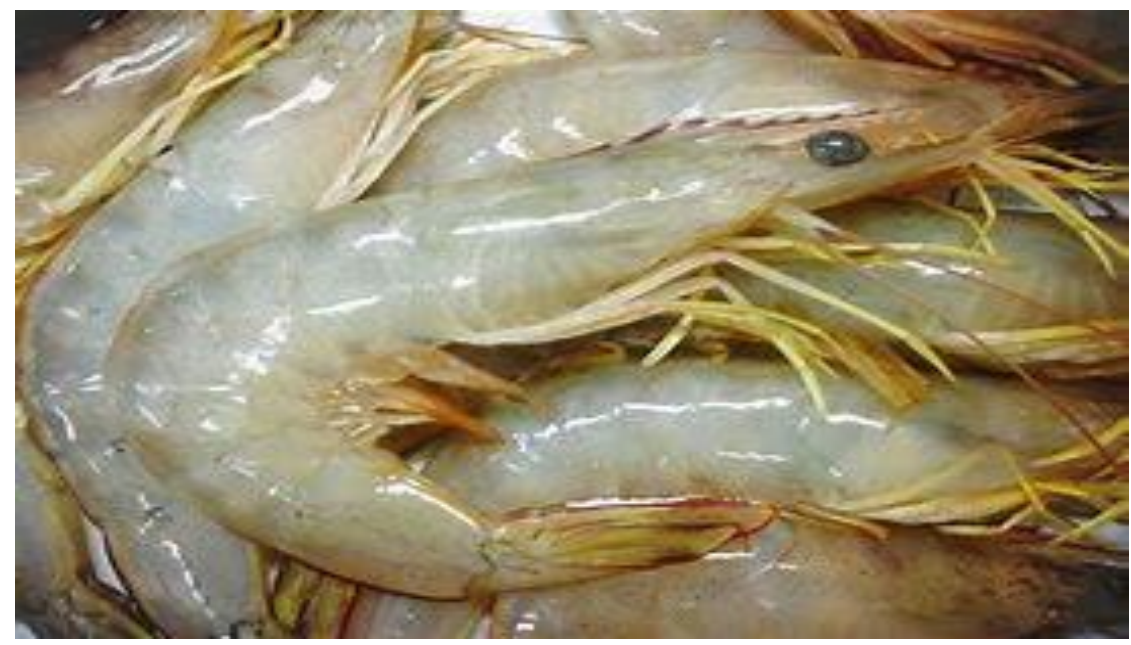

Figure 1: Shrimp (Penaeus monodon)

China is well known for the origin of shrimp. As from 1988 to 1992, China was known to be the leading shrimp producer and contributed up to one million metric tonnes of the world shrimp output in 2000 (Essays UK, 2018). But as it stands, Thailand is the biggest producer and exporter of shrimp and has taken over China. Thus Asia is known to be the major supplier in the global shrimp market (Shang et al., 1998; Ling and Leung, 1999). Shrimp together with other aquaculture products contribute $0.96 \%$ of GDP of India (Government of India, 2019). It has international trade value term of US\$12 billion (Bene and Heck, 2005).

In Nigeria shrimp business started around the 1950s (Chemonic, 2002). The aquaculture industry has grown significantly over the years, although its full potential has not yet been realized. More and speedy development is required to satisfy the growing in demand for shrimp in the world. A recent research effort to investigate the emerging shrimp market (Onashe, 2018; Achoja, 2019) highlighted shrimp market chain as the driver of economic development in Nigeria.

Nigeria has a population of 140 million (NPC, 2006) with a growth rate of $3.2 \%$. Few operators ranging from 8.23 to 18.27 million people are employed in the aquaculture value chain (including shrimp) (Anyanwu et al., 2011). Aged aquaculture farmers that are willing to continue in operational existence in the future will have a different factor combination compared to those who have intention to continue to engage in operation. Also farmers of different ages have different human capacities and investment choices (Guo et al., 2015). The consequential shortfall of human capital and the dearth of skilled manpower in shrimp value chain can only be addressed through youth inclusion and organization of shrimp culture -oriented training workshops. The demographic characteristics of the relevant players especially age classifications; the shrimp value is very fundamental to its development. Support services such as input supplies, research and development, finance, market information flow, cooperative formation and management with respect to consumer preferences as important drivers of the growth and development of shrimp chain deserve critical analysis. 
Available evidence describes African agro-based actors as an ageing population and a relatively high unemployment rate of youth, $(75 \%)$, yet youth is agent and beneficiary of development (Omodafe, 2018).

For instance, Human Capital Development index, their financial performance the aged labour population and youth inclusion rate in shrimp value chain actors, deserve a thorough investigation in the present context youth inclusion rate is operationally defined as the proportion of youth participation in the shrimp value chain. Youth inclusion in shrimp- based business presents some merits in terms of employment, long term safe take-over and survival of the sector in the future. A good proportion of agricultural- related business in Nigeria has the feature of youth involvement. Empirical studies reported the involvement of in business. Involvement of youth in shrimp value chain activities has the potential of reducing the challenge of the ageing farm population.

There is a significant wild shrimp capture in the industry that is capable of generating USD 57 million and annually for foreign exchange (Chemonic, 2002). Nigeria is among tropical countries endowed with rich shrimp resources. According to Dublin-Green and Tobor (1992), the coastal waters of Nigeria are characterized by an abundance of important living resources including shrimp. With a production capacity of 12,000 metric tons (MT) per year, Nigeria's shrimp supply is presently from capture fisheries (Dublin-Green and Tobor, 1992).

Increasing human population and the soaring per capita demand for shrimp has created a demandsupply gap. Nigeria has natural supply of shrimps, but with the declining shrimp capture there is a need to scale up shrimp aquaculture value chain operations. Nigeria is regarded as a potential frontier in the shrimp business because of its numerous coastal and mangrove areas.

Presently, Nigeria has low shrimp value chain development. The potential can be maximized active youth participation is expected to boost in areas such as shrimp input supply, artisans shrimp harvesting, processing, marketing (i.e. wholesale and retailing) and transportation (Achoja, 2019). The concern for a well functional value chain that drives growth, employment and economic prosperity among fisher folk has generated growing research interest and debates in recent times.

The relationship between activities of the value chain and financial benefits to youth is necessary to justify their inclusion and investment in the shrimp business. It has been suggested that the development of aquaculture value chain in Nigeria is hampered by inactive youth participation (Ogbonna, 2001).

Profit is the bottom line of every business and has the ability to sustain the interest of investors in business (Achoja, 2013). Against this back drop, a critical analysis of the profit performance of youth participants in shrimp value chain is warranted. The study reported financial information on participating youth in shrimp value chain and how it can sustain the industry in Nigeria. Reporting financial information of participating youth in shrimp value chain can encourage more youth participation and the development of the shrimp industry. Furthermore, the quitting preference of elderly operators from shrimp value chain has been declared in previous work (Achoja, 2019).

The decreasing number of young farmers is worrisome tendency over past decades in America and European countries. The European Union has employed a strategy of Young Farmer payment to address the age imbalance. The strategy provides an extra payment on the average base payment as spelt out in the Common Agricultural Policy reform (May et al., 2019).

Unless this is dealt with, the progress and future sustainability of the shrimp industry will be bleak at best. As it stands, strategic inclusion of youth in shrimp value chain has been understudied. Human capital could impact youth' profitability in shrimp value chain. Yet empirical information on the relationship between human capital and performance of youth in shrimp value chain is 
lacking in literature. This study is important in bridging this knowledge gap. This study was therefore conceived, conceptualized and conducted to extend the frontier of knowledge on the exit rate of the aged people and the entry rate of youth in the shrimp industry.

The objective of the study should be arranged as:

i. describe the shrimp - based agribusiness value chain mapping;

ii. examine the financial performance of youth and aged operators in shrimp value chain;

iii. determine the effect of Human Capital (HC) on the financial performance of youths in shrimp value chain.

The following hypothesis were formulated and tested to guide the study:

Ho $_{1}$ : Human Capital has no significant effect on the financial performance of youth operators in shrimp value chain.

\section{MATERIALS AND METHODS}

\subsection{Study area, sampling techniques and sample size}

The study was carried out in Delta State, Nigeria in 2018. The study area was selected for the investigation because shrimp business is the source of livelihood to on any people in the area. The common languages of Deltan people are English, Urhobo, Isoko, Ijaw and Itsekiri. The mangrove swamp forest is common Delta State with annual rainfall ranging from about $2500 \mathrm{~mm}-2800 \mathrm{~mm}$. Fishing activities including artisans shrimp are the dominant economic activity of the people.

The population for the study included the shrimp producers, processors and marketers in the shrimp value chain in the study area. A multiple sampling process was systematically used to obtain the sample for study from the sampling frame. The sampling frame (a list of operators) was generated from the list of registered shrimp producers, processors and marketers in the shrimp value chain in the study area. Systematic sampling technique was used to draw the sample of 120 respondents. The breakdown of the sample is as follows: six communities were involved in the study. In each community, on the basis of the relatively few shrimp producers and processors, 10 shrimp producers, 10 processor and 20 marketers were selected randomly. This gave a total of 240 respondents.

\subsection{Methods of data collection and analysis}

Primary data were used for the study. Questionnaire was a data collection instrument that was used. The data for this study were analyzed using both descriptive and inferential statistics. The level of profitability in shrimp value chain was achieved using the profit function as following

$$
N_{i}=T R-T C
$$

Where:

$\mathrm{N}_{\mathrm{i}}=$ Net income

$\mathrm{TR}=$ Total revenue

$\mathrm{TC}=$ Total cost $($ total variable cost + total fixed cost $)$

The effect of human capital on the financial performance of youths in shrimp value chain was achieved by simple regression equation presented as:

Youths' financial performance factors:

$$
\pi_{y}=f(\text { Human capital })
$$


The model is presented explicitly as:

$$
\pi_{y}=\beta_{0}+\beta_{1} H_{\text {cap }}+e_{i}
$$

\section{RESULTS AND DISCUSSION}

\subsection{Description of captured shrimp-based agribusiness value chain map in Nigeria}

The captured shrimp agribusiness value chains mapping in Nigeria in Figure. 1 shows the support services such as input supplies, research and development, finance, market information flow, cooperative formation and management with respect to consumer preferences as important drivers of growth and development of shrimp value chain deserve critical analysis.

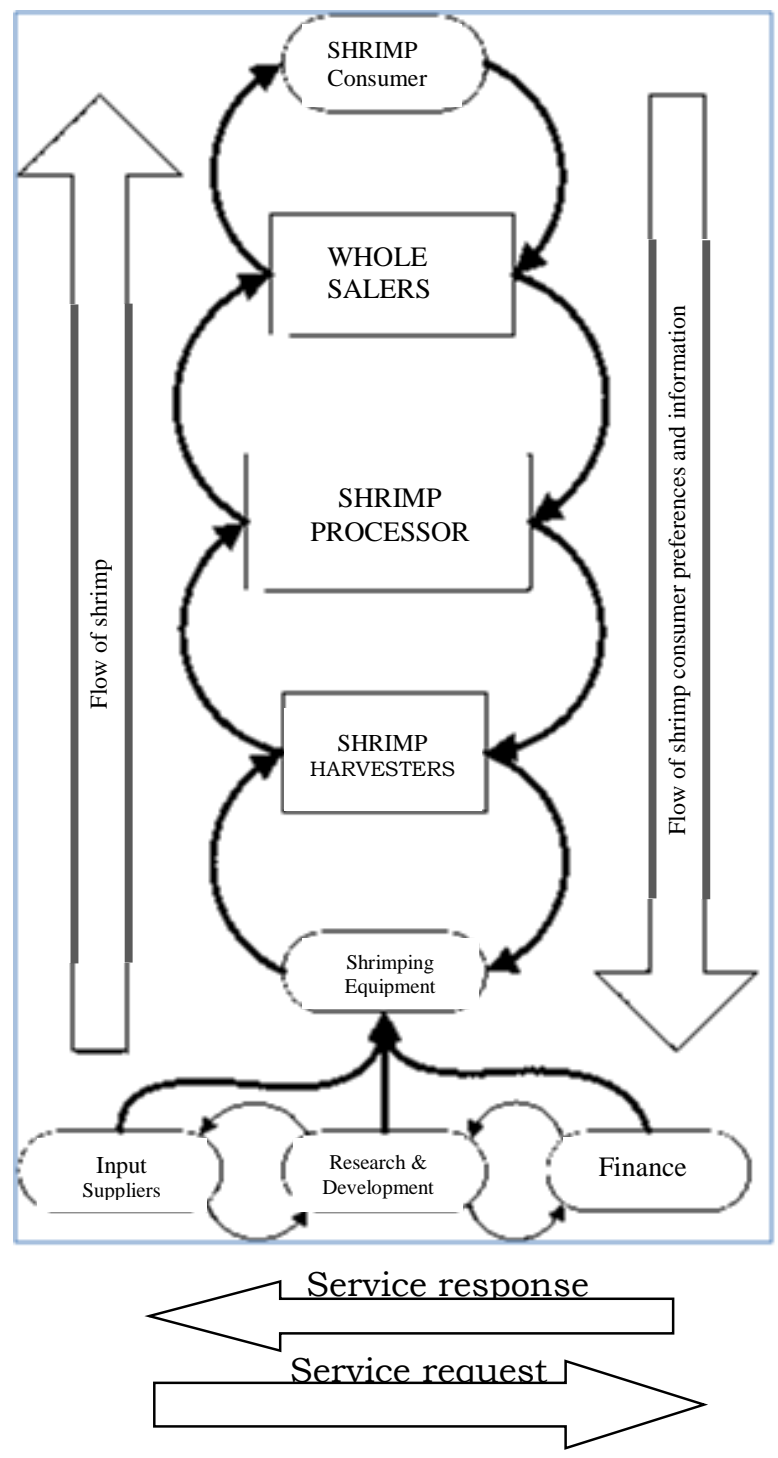

Figure 1: Adapted and modified from Smehro (2008). A value chains marketing system. From the Focus Group Discussion held with the relevant stakeholders, the shrimp value chain in value chains analytical framework in Figure 1 shows the structural linkages of the players in shrimp value chain/input suppliers, artisan's shrimpers, processors, traders and final consumers. 
Input suppliers send improved and new technology and financial services request signals to $R \& D$ and finance component of the chain. Finance is the life-blood of the value chain. All the components of the chain require finance for proper functioning. So financial and technology service responses are generated by the financial sector and $R \& D$ respectively.

Value chain is the connectivity of business actors and activities geared towards the flow of value in addition to a particular product line from input suppliers' end to product consumption end. The shrimp value chain development is enhanced by the financial sector and services provided by R\&D.

The captured shrimp-based agribusiness value chain in Nigeria can be described as follows: The captured-shrimp value chain comprises of shrimp harvesters, shrimp processors and shrimp marketers. Captured-shrimp harvesters are basically artisans' harvesters of shrimp from the Warri River and its tributaries in Nigeria. They take advantage of fishing gears such as nets and baskets. The means of transportation are canoeing and sometimes engine boats (Achoja, 2019). A shrimp harvester could harvest and sell an average of $50 \mathrm{~kg}$ of shrimp per month. Shrimp processors purchased the fresh shrimps from the harvesters they de-head, cook and smoke-dry it with fuel wood as source of energy. A shrimp processor could process and sell 150kg of smoke dried shrimp in a month. Shrimp marketers are the first buyers and secondary sellers of the processed shrimp.

Shrimp marketers are categorized into shrimp wholesalers and retailers. Shrimp wholesalers buy the processed shrimp in bulk from the processors and sell in small units to the retailers who finally sell to the ultimate consumers of shrimp at the end of the value chain.

Table 1: Profit performance of youths and aged operators in shrimp value chain

\begin{tabular}{lllcccc}
\hline $\begin{array}{l}\text { S. } \\
\text { No. }\end{array}$ & Operators & & $\begin{array}{c}\text { Total } \\
\text { Revenue } \\
\mathbf{( \$ )}\end{array}$ & $\begin{array}{c}\text { Investment } \\
\text { (Total cost) } \\
\mathbf{( \$ )}\end{array}$ & $\begin{array}{c}\text { Net } \\
\text { Income } \\
\mathbf{( \$ )}\end{array}$ & $\begin{array}{c}\text { Net } \\
\text { income/Investment } \\
\text { ratio (BCR) }\end{array}$ \\
\hline \multirow{2}{*}{1} & Input & Youth & 102.97 & 32.14 & 57 & 1.77 \\
& suppliers & Old people & 83.33 & 40 & 43.33 & 1.08 \\
2 & Producers & Youth & 272.42 & 28.61 & 203.33 & 7.86 \\
& Old people & 195.83 & 28.61 & 167.22 & 5.84 \\
3 & Processors & Youth & 157.43 & 46.11 & 111.32 & 2.41 \\
& & Old people & 111.81 & 11.25 & 100.56 & 8.93 \\
\hline 4 & \multirow{2}{*}{ Marketers } & & & & & \\
& \multirow{2}{*}{ Wholesalers } & Youth & 140.61 & 37.97 & 74.86 & 2.70 \\
& & Old people & 117.50 & 65.28 & 51.39 & 0.80 \\
& \multirow{2}{*}{ Retailers } & Youth & 84.72 & 40.28 & 66.67 & 1.66 \\
& & Old people & 99.17 & 47.08 & 52.08 & 1.11 \\
\hline
\end{tabular}

3.2. Mean profit performance of the aged and youth operators in shrimp agribusiness

$$
\begin{aligned}
& \text { Youth }=56.94+218.33+111.32+102.64+66.67=\frac{555.90}{5}=\$ 111.18 \\
& \text { Aged }=43.33+100.56+52.22+52.08=\frac{\$ 415.42}{5}=\$ 27.53
\end{aligned}
$$

Table 1 present the distribution of profit performance of youth and aged operators in shrimp value chain in the study area. The result shows that all the youth in shrimp value chain earned an average of $\$ 111.18$ per month while the aged operators earned an average income of $\$ 27.53$ per month. This result implies that the youth though few in number, earned more income per operator than the 
aged operators. This finding agrees with Omodafe (2018) who reported a high financial performance among youth in aquaculture.

Table 2: Human capital as a determinant of financial performance of youths in capturedshrimp-based agribusiness value chain

\begin{tabular}{lcc}
\hline Variable & OLS estimate & t-value \\
\hline Constant & 0.019 & 0.973 \\
Human Capital & 0.074 & $12.986^{* *}$ \\
\hline
\end{tabular}

** and * significant at $1 \%$ and $5 \%$ level respectively. $\mathrm{R}^{2}(\operatorname{adj})=42 \%$

Youths financial performance $\left(\AA_{\mathrm{y}}\right)=\mathrm{f}($ Human capital $)$

$$
\mathrm{s}_{\mathrm{y}}=\begin{gathered}
0.019+0.074 \mathrm{HC}+\mu \\
(0.973)(12.986 * *)
\end{gathered}
$$

Table 2 and equation 4 shows the result of OLS estimated relationship between human capital of youth and their financial performance in shrimp value chain. This finding demonstrates that human capital of youth (education and workshops attended) has a positive and significant ( $<<0.01)$ effect on their financial performance. The result suggests that an additional year spent in school plus additional workshop attended on shrimp related business will translate to $0.07 \%$ increase in their financial performance in shrimp value chain. Years spent in school and workshops attended must have boosted the human capital of youth and hence their contribution to the development of shrimp value chain. Young operators will not be capable of optimizing their operations in shrimp value chain without information networking and professional education. This finding supports the earlier report of Dev and Hossain (1996) who reported that agricultural knowledge oriented education has a significant effect on agricultural output (including shrimp business). Also Borisov et al. (2019) concluded that the application of education, innovation and knowledge is the key factors of success among young operators in agro-based enterprises.

\section{CONCLUSION}

The thrust of this study was to investigate how upgrading of youth' capacity can drive the development in shrimp-based agribusiness value chain in Nigeria. We found out that although, youth operators were few in the agribusiness chain, they generated more financial resources to the economy of the aged counterparts. This implies that youth operators are the major agents that drive growth of the shrimp sub-sector in Nigeria. Another noteworthy result achieved was the validation of the research hypothesis that youth's capacity upgrading through relevant education, training, workshops and credit access (human capital) proved to be positively correlated with financial performance and hence the development of shrimp value chain in Nigeria. Confirming with previous literature reviewed, youthful strength and resourcefulness would influence financial performance of shrimp agribusiness value chain. Human capital exerted a positive influence on the financial performance of the youth in the value chain. Human capital of youth in shrimp value chain therefore, should be viewed as a source of impetus to the development and growth of the shrimp industry in Nigeria. Youths are important agents of development of shrimp-based value chain. As a result, youth participation in aquaculture oriented education should be encouraged by the state. We suggest that more youth should be given opportunities and incentives to operate better in the shrimp agribusiness value chain. Upgrading the capacity of the youth operators will require strategies such as access to loans and shrimp oriented human capital development programme to encourage their participation in shrimp value chain. 


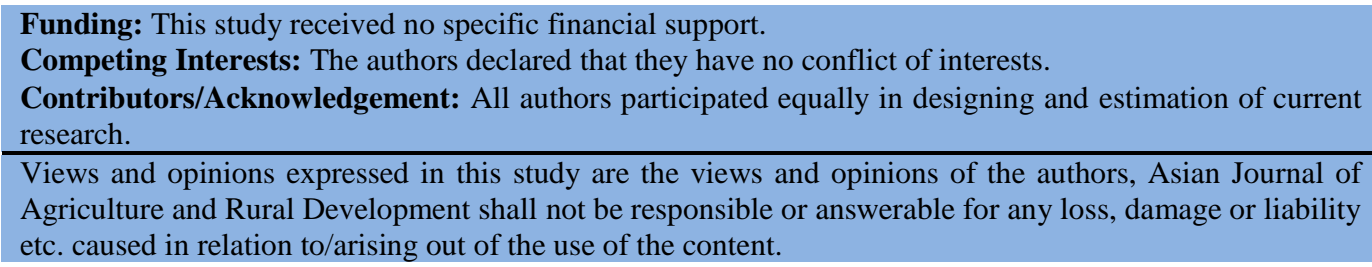

\section{References}

Achoja, F. O. (2013). Financial risk threshold determination in broiler enterprise in Delta State in Nigeria. Agricultural Tropica et Subtropica, 46(14), 111-117.

Achoja, F. O. (2019). Analysis of profitability in shrimp value chain in Delta state, Nigeria, Ege Journal of Fisheries and Aquatic Sciences, 36(2), 125-133. https://doi.org/10.12714/egejfas.2019.36.2.04.

Amos, W. H., \& Amos. S. H. (1997). National Audubon Society Nature Guides: Atlantic and Gulf Coasts. Alfred A. Knopf, Inc., New York, USA.

Anyanwu, P. E., Ayinla, O. A., Ebonwu, B. I., Ayaobu-Cookey, I. K., Hamzat, M. B., Ihimekpen, A. F., Matanmi, M. A. Afolabi, E. S., Ajijo, M. R., \& Olaluwoye, B. L. (2011). Culture Possibilities of Penaeus monodon in Nigeria. Journal of Fisheries and Aquatic Science, 6, 499-505.

Bene, C., \& Heck, S. (2005). Fish and food security in Africa. World Fish Centre Quarterly, $28(2$ and 3), 8-13.

Borisov, P., Radev, T., \& Nikolov, D. (2019). Young farmers and new entrants in Bulgarian agriculture - profiling their challenges and needs. Agriculture Economics and Management, 64(2), 60-71.

Chemonic (2002). Subsector assessment of the Nigerian shrimp and prawn industry. Chemonic International Inc. Retrieved from www.hubrural.org/IMG/pdf/nigeria_shrimp_and_prawns_subsector_assessment.pdf.

Dev, U. K., \& Hossain, M. (1996). Effect of education on technology adoption and aggregate crop output in Bangladesh. Bangladesh Journal of Agricultural Economics, 19 (1 \& 2), 1-15.

Dublin-Green J., \& Tobor, G. (1992). Fin and shellfish of conservation interest in Nigeria. Nigerian institute for oceanography and marine research, Technical Paper, 79.

Essays, U. K. (2018). The World Shrimp Production. Retrieved from https://www.ukessays.com/essays/economics/the-world-shrimp-production.php?vref=1.

Government of India (2019). Sector-wise contribution of GDP of India. Planning Commission, Ministry of Statistics and Programme Implementation (2018-2019). Retrieved from http://planninningcommission.gov.in/data/datatable_2312/DdatabookDec20142.pdf.

Guo, G., Wen, Q., \& Zhu, J. (2015). The impact of aging agricultural labour population on farmland output: From the perspective of farmer preferences. Mathematical problems in Engineering (special volume), 1-7. http//dx_doi.org/10.1155/2015/730618.

Lawal-Are A. O., \& Akinjogunla, V. F. (2012). Penaeus notialis (Pink Shrimps): Length-weight relationships and condition factor in Lagos Lagoon, South West, Nigeria. Science and Technology, 2(3), 32-40. DOI: 10.5923/j.scit.20120203.02.

Ling, B. H., \& Leung, P. S. (1999). Comparing Asian shrimp farming: the domestic resource cost approach. Aquaculture, 175(1-2), 31-48.

May, D., Arancibiaa, S., Behrendta, K., \& Adamsa, J. (2019). Preventing young farmers from leaving the farm: Investigating the effectiveness of the young farmer payment using a behavioural approach. Land Use Policy, 82, 317-327.

NPC (2006). National population commission report. Nigeria: Federal Bureau of Statistics.

Ogbonna, J. C. (2001). Reducing the impact of tropical Shrimp trawling fisheries on the living marine resources through the adoption of environmentally friendly techniques and practices in Nigeria. Ropical Shrimp Fisheries and Their Impact on Living Resources, FAO Fisheries Circular No. 974 FIIT/C974. Retrieved from 
http://www.fao.org/docrep/007/y2859e/y2859e00.htm.

Omodafe, C. O. (2018). Profitability of government assisted fish farming among youths in Delta state, Nigeria. (Unpublished MSc. Dissertation), Department of Agricultural Economics and Extension, Delta state University, Asaba campus Nigeria.

Onashe, B. O. (2018). Profitabibility analysis of shrimp marketing in Warri south west local government area, Delta state, Nigeria. (Unpublished B. Agric. Project work), Department of Agricultural Economics and Extension, Delta state University, Asaba campus Nigeria.

Shang, Y. C., Leung, P., \& Bith-Hong, L. (1998). Comparative economics of shrimp farming in Asia. Aquaculture, 164(1-4), 183-200. https://doi.org/10.1016/S0044-8486(98)00186-0.

Smehro (2008). A value chain marketing system. Retrieved from https://smehro.files.wordpress.com/2018/11/value-chain-marketing-system. 